\title{
The Role of Family Policy in Solving Demographic Problems: Study of the Polish Program Family 500+
}

\author{
By Sławomir Wilk ${ }^{1}$
}

\begin{abstract}
This article offers a critical reflection on the Programme "Family 500+" introduced by the Polish government and aimed at improving the financial situation of Polish families in order to increase the fertility rate. Families have been supported with the benefit of 500 PLN given for each child under 18. The article presents the results of the research carried out in 2019 on the representatives of the households $(\mathrm{N}=3347)$. The interviewees most frequently pointed to the increase of the quality of living conditions and the increase in the consumption of goods and services. Approximately $80 \%$ of the interviewees have noticed the fact that the benefit boosted potential development of children by enabling them to participate in the extracurricular activities and visit leisure centers. $64,7 \%$ of the interviewees believe that the Programme let them have savings and $17,8 \%$ of respondents claim that the benefit will not contribute to their savings but will be consumed on a day-to-day basis. Despite the initial assumptions of the Programme, the policy of pronatalism was not achieved as the fertility rate did not reach the assumed level. It must be stated that even though the legislative activities constitute a milestone in the Polish pro-family policy these solutions have many disadvantages. The Programme should not be the main tool of the Polish demographic policy but just supplementary.
\end{abstract}

Keywords: Family 500+ Programme; family policy; demographic policy; State Aid for Child Support Act; housebold finance; family benefits

\section{Thesis Statement}

\subsection{General characteristics}

Family 500+ Programme was introduced on $1^{\text {st }}$ in 2016 in Poland under the rule of the Law and Justice party (PiS). It is financial support in the form of a benefit of 500 PLN that was given to families for the second and other children under 18 regardless of the family income. In case of the families with the income below 800 PLN per person (or 1200 PLN in case of upbringing a handicapped child) the support was given for the first or only child as well. The State Aid for Child Support Act from 11th February 2016 (Dziennik Ustaw [Journal of Laws] . z 2017 r. poz. 1851 z późn. zm), which states the conditions of being entitled to get the benefit and the rules of conferring and paying out the benefit. Since 1st July 2019 the amended State Aid for Child Support Act has been in force which introduced changes in the Family 500+ Programme. Child benefit has been granted for all children under 18, regardless of the family income. Beneficiaries are obliged to upgrade the benefit annually as it is in case of child allowance and alimony. Child support benefit is not taken into account when the right to other benefits is granted, such as social assistance, family benefits, scholarship and housing allowance. Family 500+ Programme targets persons upbringing children and fulfills three basis aims: pro-family, an investment in human capital and decrease in poverty among the 
youngest.

\subsection{Family 500+ Programme versus Polish pro-family policy}

$500+$ benefit is an example of intergenerational public transfer (Świecka, 2017) directed by the state at the families upbringing children under 18. According to the research (Szarfenberg, 2018) the support contributes to the decrease in poverty in Poland, especially in large families (Brzeziński, Najsztub, 2018). A similar scheme can be observed in other countries (Popova, 2016). It can be found in the literature that money transfers are significant for the families for health, educational and employability reasons as well as higher salaries when the children grow up (Aizer et al. 2016; Carneiro et al. 2015). It has been observed that beneficiaries happen to be reluctant to search for a job or to continue their employment, especially in case of the persons with low income (Blundell et al. 2000; Haan, Myck, 2007) and among Polish mothers (Myck, 2016; Magda, Kiełczewska, Brandt, 2018). Parents who were granted the 500+ benefits who had at least two children are more professionally active than one child families (Kmieć 2019). In general, the authorities could be satisfied with the pro-family effects of the 500+ Programme. In 2018 there were 13 thousand children born less than in 2017 (Table 1). It should be emphasized that additional money is not enough as without proper comprehensive pro-family policy the situation will deteriorate as the number of women is decreasing and fewer of them makes a decision to give birth to a baby. Besides, as a result of cultural changes, older women decide to become pregnant (Kotowska, 2014). As a consequence, the number of born children and the number of women at a childbearing age go down at a similar pace. Thus, fertility rate might remained at the same range and the Family 500+ Programme will not influence the increase of the birth rate in Poland.

Table 1: Birth rates in Poland and in Małopolskie and Podkarpackie voivodships

\begin{tabular}{|c|c|c|c|c|c|c|c|c|}
\hline \multirow{2}{*}{ Area } & \multicolumn{8}{|c|}{ Births } \\
\hline & 2011 & 2012 & 2013 & 2014 & 2015 & 2016 & 2017 & 2018 \\
\hline Poland & 388416 & 386257 & 369576 & 375160 & 369308 & 382257 & 401982 & 388178 \\
\hline Małopolskie Voivodship & 35524 & 35117 & 34307 & 34419 & 34721 & 36331 & 38161 & 37864 \\
\hline Podkarpackie Voivodship & 21130 & 21064 & 20373 & 19953 & 19566 & 20262 & 21927 & 21533 \\
\hline
\end{tabular}

\section{Methodology}

The results presented in the article come from the research 'Socio-economic condition of Polish families in Podkarpackie and Małopolskie Voivodships with a focus on the occurrence of depopulation' carried out for the Marshall Office of the Podkarpackie Voivodeship (Leader) and its Partners: Marshall Office of the Małopolskie Voivodeship, Statistics Office in Rzeszów and the University of Rzeszów. The research was co-financed from the resources of the European Cohesion Fund under Technical Assisatnce Operational Programme in the years 2014-2020.

The main aim of the research exploration was the diagnosis of structure and functioning of the contemporary families and their living conditions in the selected aspects as well as 
providing further details to the projections concerned with the demographic changes and intensity of depopulation processes.

The research was conducted in 2019 on the representatives of households by the means of the mobile devices. Each time interviewees with the best knowledge about family situation were chosen. The issue of the research tool focused on the implementation of the family functions, identification of the most significant problems and needs, revision of the living conditions and the forms of received support.

The influence of the Family 500+ Programme on the life of the families in the southeastern Poland was verified. Total number of the computer assisted personal interview (CAPIs) in the Podkarpackie and Małopolskie voivodships (regions) was 3347. The research was representative for each of the regions. For analytical reasons the results from two voivodships were brought together. The main research outcomes were presented in the reports $(2019 \mathrm{a}, 2019 \mathrm{~b})$. To illustrate quantitative data, 120 statements from individual in-depth interview (IDI) with representatives from different types of families were presented. The main research question which the author would like to find an answer to is the estimation of the influence of the Family 500+ Programme on the families in the south-eastern Poland.

\section{Results}

\subsection{Opinion on the Family 500+ Programme}

The influence of the Family 500+ Programme on the various aspects of households was an element of analyses of the data from the statements of the representatives of CAPIs. The interviewees $(\mathrm{N}=3347)$ were asked about the influence of the Family 500+ Programme on the decision about extending the family. The vast majority of the interviewees (59.4\%) confirmed such an influence. However, 22.6\% denied and 18\% were unable to answer such a question. Collected data indicate that interviewees share the view that the benefit contributes to the increase of the fertility rate in Polish families. The interviewees of IDIs also emphasized the pro-family aim.

I have an only child and this 500+ benefit will probably make us want another child, for the time being my wife does not want to resign from her job (Interview Rzeszów, 1 child, parents professionally active).

In addition, the majority of the respondents claim that Family 500+ Programme increases the development opportunities of children. It was approved by the $81.7 \%$ of the interviewees. Only $6.6 \%$ of the respondents did not agree with such a statement and $11.7 \%$ chose 'I don't know" answer.

Hmmm ... 500+ ... that was what we needed to pay for extra classes of our children (Interview Łańcut, family with three children, parents professionally active).

In the research $64.7 \%$ of the interviewees claimed that the sources from the Programme will be saved for the child. Similarly, $17.8 \%$ did not support such an idea and $17.5 \%$ was of no opinion. One of the interviewees said:

...for the child, to buy him something, to go somewhere, but we want the money, I wanted, to save it for the child (Interview Nowa Dęba, a family with one child, parents professionally active).

Almost 4/5 of the participants noticed that Family 500+ Programme had an impact on the increase of the availability of such leisure places as a swimming pool or a cinema 
(78.9\%). 8.5\% did not agree with the statement, $12.6 \%$ was not sure whether there was any impact or not. The interviewees amply described spending the money on leisure.

It is irritating when at school they tell the kids to ask mum for the money as they get 500+ PLN so they can give 500+ for the books, some other silly things.... It is like that everywhere... (Interview Kołaczyce, foster family with 6 children, parents professionally active).

For example, I know a family, their daughter goes to school with our son, and the parents don't work and have time for everything - a swimming pool, a playground and they get the money from the State. And they deserve it..., don't they?! (Interview Przeworsk 1, family with 1 child, parents professionally active).

Even bigger percentage of the interviewees confirmed that the Family 500+ Programme increases the quality of family life $(84.9 \%) .7 .1 \%$ of the respondents denied that and $8.0 \%$ was of no opinion.

Now, I can plan e.g. holidays or I have recently bought a scooter for my son because I could afford it. Before, I would have to think it over carefully. And I save up for the future (Interview Rzeszów15.07, family with 3 children, a self-employed father, a mother is a housewife).

For the majority of the respondents it was almost obvious that the Family 500+ Programme increased the consumption of both goods and services. It was confirmed by $85.4 \%$ of the interviewees and denied by $6.6 \%$. Answer 'I don't know' was chosen by $8.0 \%$. The respondents indicated in IDI the impact of the Programme on satisfying the goods.

Dressing the blighters... for clothes. A pair of shoes costs 80PLN. And how long does he use the shoes? He grows up so fast. For clothes, for food (Interview Pełnatycze, family with 5 children, wife employed, husband works sporadically).

Parents have started organizing big birthday parties since the 500+ Programme, so they booked a place with a playground and invited the whole group. This could be because of the Programme (Interview Przemyśl 1, family with 1 child with an adult child, parents are professionally active).

For sure, it was useful. Even when it comes to some basic items, such as milk or diapers or. yeah, these things cost a lot and you got the money for it. You don't put the money aside because it is not enough, but it helped a lot. It helped with the upbringing of the kids (Interview Dębica, family with 2 children under six, parents professionally actively).

The interviewees were asked a question: "In your opinion, does the Family 500+ Programme has an impact on the occupational life of the family members - job resignation? The respondents found it difficult to notice the influence of the Programme on the occupational change of the family members and job resignation. $41.9 \%$ of the interviewees confirmed such an impact and 35.5\% denied it. More than $1 / 5$ of the respondents was unable to answer such a question. During the interviews the respondents commented on the issue in a following way:

I don't understand the people who resign from a job to get the money. I was so happy to find a job and leave home and no 500+ would have made me stay at home. It should motivate and be related to the employment. It is logical. I know some people who resign from a job to get the money (Interview Cmolas, family with 3 children, parents professionally actively).

Some got the 500+ and ignore everything (Interview Pełnatycze, family with 5 children, wife employed, husband works sporadically).

Then, a following question was asked: In your opinion, does the Family 500+ Programme has an impact on the occupational life of the family members - starting a job? According to the 
interviewees, the Family 500+ Programme does not affect the occupational situation of the Polish families in relation to starting a job (53.5\%). Such a situation was declared by $21.1 \%$ and $25.4 \%$ did not give an answer. One of the interviewees said during an IDI:

I think the money should be given to families, in which at least one parent works. I know what I am saying because a woman lives in the house next-door who has seven children. There is an on-going party all the time, probably only two children have the same father and she jokes that she earns more money than the head of the Social Welfare Centre. And she isn't going to look for a job. She doesn't take care of the children. Everybody around care about the children but she doesn't. (Interview Jarostaw, family with 3 chidlren, two of whom are university students parents professionally actively).

Next, the interviewees were asked to specify how the Family 500+ Programme influenced the occupational situation of the family members. It turned out that almost $3 / 4$ of the respondents $(73.4 \%)$ declared that the Programme did not change their occupational situation in their household and more than $1 / 5$ of the interviewees stated that the issue did not apply to them as they did not get such a support - no school children or senior households $(21.4 \%)$. In the opinion of $3.3 \%$ of the interviewees the Programme had an impact on the decision to resign from the main job. Moreover, $0.8 \%$ of the respondents stated that the Programme affected their occupational life in some other way.

It won't affect because I will not quit my business activity for 500PLN a month. My wife won't do that either for 500PLN, which is spent on the child anyway (Interview Krasna, family with 1 child, parents professionally active).

One of the interviewees commented on his wife's opportunity to start a job:

We don't approve of the nurseries. We have 500+, we get 1500PLN. There is no point for my wife to work she'd better help me with my business (Interview Rzeszów, 15.07, family with 3 children, father is self-employed, mother is a housewife).

\subsection{Opinion on the Family 500+ Programme versus sex}

In order to verify whether there is any correlation between the opinions and the sex of the respondents commenting on the influence of the Programme on various aspects of life described above the Pearson chi-square test was applied. It turned out that in case of almost all of the answers there is a significant statistical correlation and the result can be generalized to the whole population $(\mathrm{p}<0,05)$, however, it is very weak as the Pearson correlation coefficient shows, in each correlation it is less than 0.2 . There was no dependence between the answer and sex noted when it comes to the question about the influence of the Programme on the increase of the quality of family life. Furthermore, the Pearson chi-square test could not be applied to compare the question about the impact of the Programme 500+ on the occupational situation of the members of the households with the sex due to a small sample size $(30 \%)$.

\subsection{Opinion on the Family 500+ Programme versus age}

Verification of the impact of age on the respondents' view on the Family 500+ Programme allow to notice the fact that the age influences the opinion that the Family $500+$ Programme matters when a decision on having another child $(p+0.000)$ and the correlation is weak $(C=0.223)$. In other cases the Pearson chi-square test confirmed the statistically important correlation between the age and individual answers given in the 
questionnaire by the interviewees $(\mathrm{p}<0.05)$ but its strength is weak.

Responder analysis of the answers to the question about the impact of the Family $500+$ Programme shows that the older the respondents are the more of them agree with the statement that the introduction of the Programme by the Polish government affects the decision about having more children: $61.4 \%$ of respondents at the age $18-29,52.8 \%$ at the age $30-44$. Up to $67.3 \%$ of the answers confirmed such a correlation from the group of people at the age of 70 and more.

\subsection{Opinion on the Family 500+ Programme versus education}

The level of education was correlated with the respondents' opinions about the impact of the Family 500+ Programme on the individual aspects of life and starting a family. It was revealed that in case of all questions there is a statistically significant correlation (the level of education influences the opinion on the Programme) and the result can be generalized to the whole population $(p<0.05)$, but it is very weak, which is confirmed by the Pearson correlation coefficient $(\mathrm{C}<0.2)$.

\subsection{Opinion on the Family 500+ Programme versus one-person or multi-person household}

Respondents' background (one-person or multi-person household) had an impact on the perception of the influence of the Family 500+ Programme $(\mathrm{p}=0.000)$ on various aspects of the functioning of the families but the strongest correlation appeared in case of question number 1 , that is making a decision to have a family $(C=0.164)$.

Percentage figures indicate that respondents from multi-person families emphasized more often that the Family 500+ Programme does not influence their decision on having another child $(26.1 \%)$ and there were slightly more respondents from one-person households (60.4\% to 59\%) showed such an impact of the analysed support for the families.

\subsection{Opinion on the Family 500+ Programme versus household with children and without children}

Opinions on the Family 500+ Programme were determined by the fact whether the respondents lived with or without children $(\mathrm{p}=0.000)$. The strongest correlation is in case of the impact on the decision about having another child $(\mathrm{C}=0.293)$ and the influence of the Programme on the increase of the development opportunities for children (such as participation in extra-curricular educational classes) $(\mathrm{C}=0.178)$. Besides, type of the household determines the opinions on the impact of the Programme on the change of the occupational situation of the family members, that is resignation from a job $(C=0.173)$ and starting a job $(C=0.162)$.

In case of the view that the Family 500+ Programme influences the decision about having another child, the statistical data indicate that there were more respondents approving of that fact among childless interviewees (63\%) than among families with children (48.8\%). Moreover, $43.6 \%$ of the interviewees with children denied such an influence of the Programme on the decision about having more children in comparison with $15.4 \%$ of the childless respondents.

Interestingly, respondents with children confirmed that the Family 500+ Programme has 
an impact on an increase in the children's developmental opportunities $(93.2 \%)$ whereas $77.7 \%$ of the childless interviewees confirmed that fact. Childless families more often denied the impact of the support on the child's development $(7.4 \%$ to $4.1 \%)$ or they chose 'I don't know' answer $-14.8 \%$ to $2.7 \%$.

Having children increases the belief among the respondents that the Family 500+ Programme does not affect the decision about resigning from a job (45.5\% to $32 \%$ among childless families). Childless respondents more often confirmed no knowledge on such an impact (26.6\% to $10 . \%)$.

It has been noted that a type of the household (childless or with children) determines the opinion on the importance of the Family 500+Programme for the decision on starting a job. In this case $65.2 \%$ of respondents with children denied the view that the Programme had an impact on starting a new job by the family members (in comparison with $49.5 \%$ in the childless group). Interviewees from childless households more often chose 'I don't know' answer $(29.4 \%$ to $13.9 \%)$

\subsection{Opinion on the Family 500+ Programme versus number of children in the household}

Statistical analysis proved that a number of children influences the respondents' opinion on the Programme only in case of the change of the occupational situation of the family members by starting a job. The correlation is weak $(\mathrm{p}=0.000, \mathrm{C}=0.154)$. Frequency distribution indicates the fact that the increase in the number of children influences the growing belief that the Family 500+ Programme does not determine the decision to start a job. Among the respondents with one child, $59.9 \%$ of the interviewees denied such an influence whereas in case of families with two children it was $70.5 \%$ of respondents and $83.9 \%$ of interviewees with three or more children. It can be concluded that in large families other factors determine the decision to start a job.

\subsection{Opinion on the Family 500+ Programme versus the area of residence}

Neither an area of residence nor a type of the place of living (a city or a village) has a significant importance for the respondents' opinions on the impact of the financial support from the Family 500+ Programme on various aspects of families $(p>0.005)$. Statistical dependence was noted only in case of rating the impact of financial support on the better quality of family life $(\mathrm{p}=0.035, \mathrm{C}=0.045)$ and on the change of the occupational status of the family members by starting a job( $\mathrm{p}=0.016, \mathrm{C}=0.050)$, however, the correlation is very weak.

\section{Conclusions and Implications}

The Family 500+ Programme exists independently from the current support centers for families, such as family benefits or a tax relief. The results of the research in two voivodeships of south-eastern Poland show that the respondents believed most often that The Family 500+ Programme had an impact on improving the quality of family life $(84.9 \%)$ and increased the consumption of goods and services $(85.4 \%)$. More than $81 \%$ of the interviewees noticed the influence of the benefit on the increase in opportunities of children's development by participation in extra-curricular activities and 
the better access to the leisure centres (78.9\%). $64 \%$ of the respondents believed that the Programme contributed to their savings. More than a half of the interviewees perceived the increase in the birth rate as the main aim of the Programme.

The author of the welfare state concept, Otto von Bismarck, created it for a different purpose than it is implemented in Poland. According to the idea of the German chancellor, social welfare should support the people who are in trouble, such as they have lost a job or their house burnt down. The state's role is to help the affected individual to regain self-reliance. The state's policy should be based on the role of a paramedic helping in an emergency rather than a full-time helper. The Programme is a risky project when public finance is taken into account as it distributes the money regularly without any work performance. In Poland there is still no reliable analysis and strategy of social policies, which should be long term not partial and profit-oriented in short term politics.

The perception of a woman's role should be rephrased. A woman who has a stable employment with an opportunity of flexible part-time working hours and home office decides to have a child. This is why the government should implement such a policy that will encourage women's professional activity. More facilities for children should be opened (daycare) and some law on equal childcare should be implemented. Longer and paid leaves for the other parent - especially a father, could be a solution. Due to little fathers' involvement in child's care, many women decide not to have another children.

\section{References}

Aizer, A., Eli, S., Ferrie, J., \& Lleras-Muney, A. (2016). The long-run impact of cash transfers to poor families. American Economic Review, 106(4), 935-71. DOI: 10.1257/aer.20140529

Blundell, R., Duncan, A., McCrae, J., \& Meghir, C. (2000). The labour market impact of the working families' tax credit. Fiscal studies, 21(1), 75-104. https://doi.org/10.1111/j.1475-5890.2000.tb00581.x

Brzeziński, M., Najsztub, M. (2018). Wpływ programu „Rodzina 500+” na dochody gospodarstw domowych, ubóstwo i nierówność. Entrance (26.04.2020) ₹: bttp://coin. wne. uw. edu. pl/ mbrzezinski/research/rodzina500plusPolitykaSpoleczna_nowa_wersja. pdf.

Carneiro, P., Løken, K. V., \& Salvanes, K. G. (2015). A flying start? Maternity leave benefits and long-run outcomes of children. Journal of Political Economy, 123(2), 365-412. https://doi.org/10.1086/679627

Haan, P., \& Wrohlich, K. (2011). Can child care policy encourage employment and fertility?: Evidence from a structural model. Labour Economics, 18(4), 498-512. https://doi.org/10.1016/j.labeco.2010.12.008

Haan, P., Myck, M. (2007). Apply with caution: introducing UK-style in-work support in Germany. Fiscal Studies, 28(1), 43-72. https://doi.org/10.1111/j.1475-5890.2007.00047.x

Kmieć, D. (2019). Professional activity of parents receiving family $500+$ child support in rural and urban areas. Acta Scientiarum Polonorum. Oeconomia, 18(3). https://doi.org/10.22630/ASPE.2019.18.3.30

Kotowska, I. (2014). Niska dzietność w Polsce w kontekście percepcji Polaków. Warszawa: Ministerstwo Pracy $i$ Polityki Społecznej-Centrum Rozwoju Zasobów Ludzkich.

Local Databank Central Statistical Office, Entrance (26.04.2020) https://bdl.stat.gov.pl/BDL/dane/podgrup/temat

Magda, I., Kiełczewska, A., \& Brandt, N. (2018). The "Family 500+" child allowance and female labour supply in Poland. Warsaw: Institute for Structural Research.

Myck, M. (2016). Estimating Labour Supply Response to the Introduction of the Family 500+ Programme. Centre For Economic Analysis (CenEA) Working Paper Series WP01/16.

Popova, D. (2016). Distributional impacts of cash allowances for children: a microsimulation analysis for Russia and Europe. Journal of European Social Policy, 26(3), 248-267. https://doi.org/10.1177\%2F0958928716645074 
Puślecki, D. (2016). Polityka wsparcia rodziny czy stymulowanie wzrostu demograficznego w Programie Rodzina 500 plus. Przeglad Politologiczny, (3), 79-91. https://doi.org/10.14746/pp.2016.21.3.5

Raport końcowy dla województwa podkarpackiego $(2019$ a). Kondycja spoteczno-gospodarcza rodzin w województwach podkarpackim i matopolskim, ze szczególmym uwaglednieniem sjawiska depopulacji. Rzeszów: Urząd Marszałkowski Województwa Podkarpackiego

Raport końcowy dla województwa małopolskiego (2019 b). Kondycja społeczno-gospodarcza rodzin w wojewódətwach podkarpackim $i$ matopolskim, ze szczególnym unzglednieniem rjawiska depopulacji. Rzeszów: Urząd Marszałkowski Województwa Podkarpackiego

Szarfenberg, R. (2018). Ubóstwo i pogłębiona deprywacja materialna rodzin w kontekście wdrożenia" Programu 500 plus". Polityka Spokeczna, (1), 11-17.

Świecka, B. (2017). Świadczenie 500 plus jako transfer międzypokoleniowy. Przedsiębiorczość i Zarzadzanie, 18(9.3), 59-70.

Ustawa z dnia 11 lutego 2016 r. o pomocy państwa w wychowywaniu dzieci, Dz. U. 2016, poz. 195 